\title{
CHALLENGES OF HUNGARIAN HIGHER EDUCATION IN UKRAINE
}

\author{
Viktória Ferenc \\ University of Pécs
}

\begin{abstract}
Hungarians in Ukraine have a well organized educational system that covers institutions from the kindergarten to the university. At first glance it may look like that the maintenance of the Transcarpathian Hungarians in Ukraine is guaranteed, however, we have to see that minority education (which is one of the key-issue of the maintenance of the community) is threatened by several factors. In the given paper I will take under investigation only two of these factors. On the one hand the Ukrainian state language policy would like to strengthen the position of the state language even at the expense of other languages and education is used as a means of achieving these aims. On the other hand, while education is one of the effective and powerful means of achieving social goals of the minority and choosing the language of instruction is a crucial part of language education policy, minority universities neglect serious language planning activity. It is high time for every institute to work out an individual university language policy taking into account their own aims and personal conditions.
\end{abstract}

Keywords: minority education, language policy, language of instruction, universities

Apart from the fact that Ukraine considers itself a monolingual state, similarly to other territories of the country, in the most western part, namely in Transcarpathia region we can find lively ethnic and linguistic diversity. Among other nationalities a fairly large Hungarian-speaking population lives there. According to their number (159 566 people) Hungarians are among middle-size minorities of Ukraine (Shulha 1995). Their ratio within this enormous state is not large $(0,03 \%)$, nevertheless within the region they make up $12 \%$ of the local population.

Historically Hungarians in Ukraine are an indigenous minority: the region and its population belonged to the former Hungarian Kingdom until 1920, when all the people here not depending on their nationality became Czechoslovak, again Hungarian, Soviet, and then (in 1991) Ukrainian citizens without moving from their 
place. In terms of location, the majority of them live in absolutely Hungarian settlements next to the Ukrainian-Hungarian border (Orosz and Csernicskó 1999, Molnár 2004).

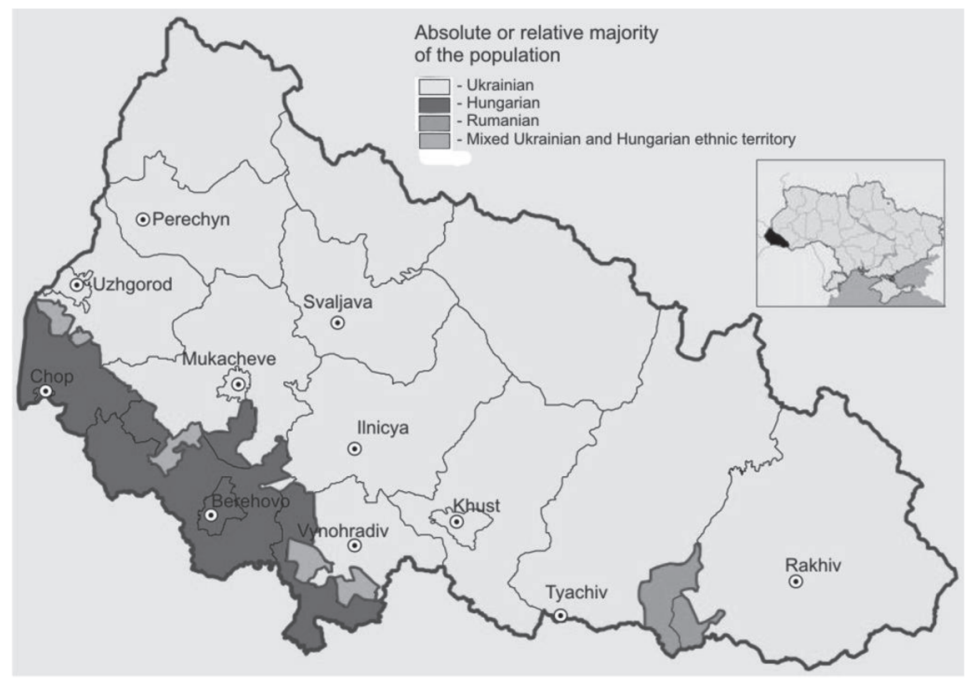

Figure 1. Hungarians in Transcarpathia region (made by Molnár D. acc. to 2001 national census data).

The Hungarians are one of the best organized minorities in the territory, strongly representing their interests. The Hungarians living in Ukraine insist on the use of their native language and 95\% of them consider Hungarian to be their mother tongue.

The Hungarian community listens mainly to Hungarian radio, watches Hungarian TV and gets information from the local Hungarian newspapers. In pure Hungarian families practically only Hungarian is used. Previously the use of Ukrainian and Russian precedes Hungarian only in offices and at workplaces (Csernicskó 1998), however nowadays the use of the state language became more and more demanding at the sphere of education too.

Hungarians in Ukraine have a well organized educational system that covers institutions from the kindergarten to the university (Shamshur and Izhevska 1994) (see Table 1). 
Table 1. The language of 13 minority communities of Ukraine on various levels of education (Csernicskó 2008).

\begin{tabular}{|c|l|l|l|l|l|l|l|l}
\hline $\begin{array}{l}\text { Minority } \\
\text { language }\end{array}$ & $\begin{array}{l}\text { Language } \\
\text { of pre- } \\
\text { school } \\
\text { education }\end{array}$ & $\begin{array}{l}\text { National } \\
\text { culture, } \\
\text { traditions }\end{array}$ & $\begin{array}{l}\text { Optional } \\
\text { subject }\end{array}$ & $\begin{array}{l}\text { Taught } \\
\text { as } \\
\text { subject }\end{array}$ & $\begin{array}{l}\text { Language } \\
\text { of } \\
\text { instruction } \\
(1 \text { st-4th } \\
\text { forms })\end{array}$ & $\begin{array}{l}\text { Language } \\
\text { of } \\
\text { instruction } \\
(5 \text { th-11th } \\
\text { forms })\end{array}$ & $\begin{array}{l}\text { Language } \\
\text { of } \\
\text { instruction } \\
\text { in } \\
\text { technical } \\
\text { training }\end{array}$ & $\begin{array}{l}\text { It is } \\
\text { taught in } \\
\text { higher } \\
\text { education }\end{array}$ \\
\hline Byelorussian & & & + & & & & & \\
\hline Bulgarian & & + & + & + & + & + & & + \\
\hline Gagaus & & + & + & + & & & & + \\
\hline Greek & & + & + & + & & & & + \\
\hline Yiddish & & + & + & + & & & & + \\
\hline $\begin{array}{c}\text { Crimean } \\
\text { Tatar }\end{array}$ & & + & + & + & + & + & & + \\
\hline Polish & + & + & + & + & + & + & & + \\
\hline Hungarian & + & + & + & + & + & + & & + \\
\hline Moldavian & + & + & + & + & + & + & & + \\
\hline German & $*$ & & $*$ & $*$ & $*$ & $*$ & & $*$ \\
\hline Russian & + & + & + & + & + & + & & + \\
\hline Romanian & & + & + & + & + & + & & + \\
\hline Slovak & & + & + & + & + & & & + \\
\hline
\end{tabular}

*Taught as a foreign language.

In all of these institutions, Hungarian language is taught not only as a language of heritage, but also used (at least partly) as a medium of instruction. The Hungarian language and education in the mother tongue are determining factors from the point of view of Ukrainian Hungarians' identity (Csernicskó ed. 2003: 232).

In terms of Hungarian higher education we must mention 16 degree programs running in 4 higher education establishments. The oldest one of them is the National University of Uzhgorod, which has long traditions in education of Hungarian philologists. In 2008 the Hungarian Department of the University was opened with four degree programs (Hungarian language and literature, Physics, Mathematics and History) where the medium of instruction is partly Hungarian. In 1996 the Transcarpathian Hungarian College was established in the city of Berehovo. In the College, which was founded by the local societal organisations, the main language of instruction is also Hungarian. Here young people have the opportunity to get education in ten different degree programs. Besides the above mentioned two institutes Hungarian is used in one degree programs of the Kyiv Slavistic University and the State University of Mukachevo (see Table 2). 
Table 2. Higher Education Establishments of Transcarpathia where Hungarian is used (at least partly) as a language of instruction.

\begin{tabular}{|c|c|c|c|c|}
\hline & $\begin{array}{l}\text { Transcarpathian } \\
\text { Hungarian } \\
\text { College named } \\
\text { after Ferenc } \\
\text { Rakoczi II. }\end{array}$ & $\begin{array}{l}\text { National } \\
\text { University of } \\
\text { Uzhgorod, } \\
\text { Hungarian } \\
\text { Faculty }\end{array}$ & $\begin{array}{l}\text { The State } \\
\text { University of } \\
\text { Mukachevo, } \\
\text { Teacher } \\
\text { training }\end{array}$ & $\begin{array}{l}\text { The Kyiv } \\
\text { Slavistic } \\
\text { University, } \\
\text { Department of } \\
\text { Hungarian } \\
\text { language and } \\
\text { literature } \\
\end{array}$ \\
\hline Established & 1996 & $\begin{array}{l}1965,2004 \\
2008\end{array}$ & 1945 & 2005 \\
\hline $\begin{array}{l}\text { Financially } \\
\text { Supported }\end{array}$ & \begin{tabular}{|l} 
Special \\
Foundation, \\
Hungary
\end{tabular} & $\begin{array}{l}\text { State of } \\
\text { Ukraine, partly } \\
\text { Hungary }\end{array}$ & Ukraine & Ukraine \\
\hline $\begin{array}{l}\text { The number of } \\
\text { degree } \\
\text { programes in } \\
\text { Hungarian }\end{array}$ & 10 & 4 & 1 & 1 \\
\hline $\begin{array}{l}\text { Degree } \\
\text { programs }\end{array}$ & $\begin{array}{l}\text { Hungarian } \\
\text { language and } \\
\text { literature } \\
\text { English language } \\
\text { Ukrainian } \\
\text { language } \\
\text { History } \\
\text { Biology } \\
\text { Mathematics } \\
\text { Geography } \\
\text { Bookkeeping } \\
\text { Teacher training } \\
\text { Kindergarten } \\
\text { teacher training }\end{array}$ & $\begin{array}{l}\text { Hungarian } \\
\text { language and } \\
\text { literature } \\
\text { History and } \\
\text { European } \\
\text { Integration } \\
\text { Physics } \\
\text { Mathematics }\end{array}$ & $\begin{array}{l}\text { Teacher } \\
\text { training }\end{array}$ & $\begin{array}{l}\text { Hungarian } \\
\text { language and } \\
\text { literature }\end{array}$ \\
\hline $\begin{array}{l}\text { Number of } \\
\text { Hungarian } \\
\text { students } \\
(2008 / 09)\end{array}$ & 1100 & 285 & 127 & 50 \\
\hline
\end{tabular}

Transcarpathian Hungarians in Ukraine is guaranteed, however, we have to see that minority education (which is one of the keyissue of the maintenance of the community) is threatened by several factors. In the given paper I will take under investigation only two of these factors which significantly impede the efficient exploitation of the possibilities hidden in the existing minority education system. 
On the one hand the Ukrainian state language policy would like to strengthen the position of the state language even at the expense of other languages and education is used as a means of achieving these aims. On the other hand, while education is one of the effective and powerful means of achieving social goals of the minority (Shohamy 2006) and choosing the language of instruction is a crucial part of language education policy, minority universities (or university departments, degree programs) neglect serious language planning activity.

The Ukrainian nation, which in 1991 got a majority position after its previous minority status, formed a language policy, which was side with the minorities. However in the recent past the aims of the state nation and language policy has been changed radically. Analysing visible sights of the state language policy (appear in press releases, interviews, ministerial statutes) we can catch out the real nature of the policy, which has the priority of strengthening the status of the state language, widening its functions, even if it means the restriction of other languages. In this process education and also higher education plays an important role.

For example, according to the minister of education, Ivan Vakarchuk, for a minority person in order to take part in quality higher education, make a carrier, realize oneself, besides his/her mother tongue the knowledge of the state language is also required. Further on he added: "For me as a minister it is clear: nobody has the right and the possibility to restrict citizens' foundational right to study and get education in the state language. I agree that every mother should sing a lullaby to her child in her mother tongue. However every citizen of Ukraine, among others national minorities too, have to integrate into the Ukrainian society and being successful by the high level knowledge of the state language."

The introduction of the joint school-leaving and entrance examination $(2008)^{2}$ can be seen as the first step of the mentioned "integration". According to the ministerial decree the traditional system based on entrance examinations was replaced by a new

1 See the minister's interview in the following website: http://www.mon.gov.ua/main.php?querz=newstmp/2008/23_10/1.

2 Наказ Міністерства освіти і науки України Про зовнішне незалежне оцінювання навчальних досягнень випускників навчальних закладів системи загальної середньої освіти, які виявили бажання вступати до вищих навчальних закладів у 2008 рощі № 1171 від 25.12.2007 p. 
system of raised level school-leaving examinations organising in independent centres. From 2007/08 academic year the final list of university students, who can enter the university is shaping only according to the points getting in the independent test centres.

In theory the introduction of the system can strengthen the quality of education and knowledge. Moreover, it can serve equal starting position for everybody. Nevertheless, the practice and the preparatory work of the joint exam show us that it is not the case, but vice versa, pupils from minority schools are at a disadvantage. Every pupil who decided to continue his/her education in tertiary level, has to take an obligatory exam in Ukrainian language and literature regardless to what language was the medium of their secondary school and what they would like to study at the university. The requirements of the examinations were absolutely the same for pupils from schools with Ukrainian as the language of instruction and pupils from nationality schools. For the Ukrainian schoolleavers it means that they have to take an exam in their mother tongue, while for minority school-leavers it was an exam in a "foreign" language which is taught ineffectively. ${ }^{3}$ Obviously a native speaker of the state language will stand a better chance to take the exam then a minority speaker who just learn Ukrainian as second language. As a consequence of this in the year of introduction (2008) $8.38 \%$ of school-leavers ${ }^{4}$ failed the Ukrainian examination (country average), while among pupils from schools with Hungarian as a medium of instruction the ratio was $29.58 \% .{ }^{5}$ In the academic year 2009/2010 9\% of the applicants failed the exam in Ukrainian language and literature, nevertheless in Transcarpathian context the ration was $15 \%$. As far as Transcarpathian Hungarians

3 In minority schools Ukrainian language is not taught as a foreign or as an environmental language, but as a second mother tongue. Teaching is carried out with the help of inappropriate books and methodological principles, which are used in teaching native Ukrainian pupils (Beregszászi and Csernicskó, 2004). As a consequence of it the level and the efficiency of the official language teaching in nationality language schools is very low. Even the Minister of Education (Ivan Vakarchuk) admitted it in his evaluation speak about the efficiency of the state language education in minority schools on March 4, 2008. According to the Minister (my translation): "It has turned out that instead of teaching Ukrainian not rarely teachers just imitate it, and the best marks were put to the certificates." See: http://www.mon.gov.ua/newstmp/2008/05_03/doc.doc

4 See: http://www.testportal.gov.ua

5 See in the newspaper Kárpátalja (June 6, 2008). 
are concerned $28 \%$ of Hungarian school-leavers (535 pupils) planed to continue their studies in tertiary education, so all of them applied for the obligatory exam in Ukrainian language, but unfortunately $49 \%$ of them failed it. ${ }^{6}$ Beginning with the 2009/2010 academic year, all the school leaving (and at the same time entrance) examinations should be taken in Ukrainian in the country.

Analysing the test in Ukrainian language and literature it has turned out that there were questions in the test, which minority school-leavers have not even learned, because it is not the part of the curriculum for minority schools. As it is shown on Table 3, the name of the subject is the same in minority language and Ukrainian medium schools, but from the point of view of the content and the number of lessons there are crucial differences between the two subjects. That is why it is impossible to measure the level of knowledge of the two groups with the same test.

Table 3. Lesson numbers in a week of the subject Ukrainian language in minority language and Ukrainian medium schools. ${ }^{7}$

\begin{tabular}{|l|l|l|l|l|l|l|l|l|l|}
\hline Grades & 5 & 6 & 7 & 8 & 9 & 10 & 11 & 12 & Total \\
\hline Ukrainian medium school & 3.5 & 3 & 3 & 2 & 2 & 2 & 2 & 2 & 19.5 \\
\hline Minority language medium school & 3 & 3 & 2 & 2 & 2 & 1 & 1 & 1.5 & 15.5 \\
\hline
\end{tabular}

Apart from the exam in Ukrainian language and literature, school-leavers have to take two more exams according to the chosen speciality. The statute orders that the language of the exam, the test sheets, and the instruction should only be Ukrainian. However, after a long protest of minority organisations against the discriminative decree, with a special permission (but not safeguarded by law) the translation of the tests in a temporary period (2007/08 and 2008/09) was allowed. Nevertheless according to a ministerial decree from 2010 all of the joint school-leaving and entrance examinations should be taken in Ukrainian language.

Another really strange consequence of the new system is that for an applicant of Hungarian language and literature or Romanian language and literature degree program the joint examination in the state language is obligatory, but from the chosen special-

\footnotetext{
See in the newspaper Kárpátalja (July 24, 2009).

The number of lesson adopted by the Ministry of Education and Science. See the official website: http://www.mon.gov.ua
} 
ity nobody can test the applicant's knowledge (since Hungarian or Romanian language can not be chosen as an exam, and universities are not allowed to organise an own entrance examination). As a consequence of this quite a lot Ukrainian school-leaver (who do not have the appropriate level in Hungarian language) applied to specialities where the language of instruction is Hungarian. They decided to chose the Hungarian programme because according to their points, in the parallel Ukrainian programme they would not get financially supported places, while here in the Hungarian program their point were still higher then points of Hungarian school leavers. So the Ukrainian pupils got the financially supported places in programs which have been found especially for Hungarians.

Another aspect of the state education policy which makes difficult for minority languages to hold their present position in higher education is the ideology which appears in the draft version of the new Law on higher education. Ivan Vakarchuk, the Minister of Education in one of his speech on 21th of March, 2008, said (my translation): "One of the most important tasks of the Ministry of Education and Science is the overall introduction of state language education in the higher educational institutions." "In accordance with the citation the Minister has already promoted the draft, which states (clause 5) that in Ukraine the language of higher education is Ukrainian, moreover lectures should be hold in Ukrainian in foreign language degree programs too, and only examples can be said in the target language.

As a first step of the realization of the above mentioned thoughts in 2008 spring, the Ministry of Education required the higher educational institutions to provide statistics within a given deadline about the number of courses which are taught in the institution in Ukrainian and how many are taught in an other language. ${ }^{9}$

After that in 2009 spring, in his evaluation speech the Minister of Education sorry to consider that in the country's higher education establishments at $\mathrm{BA} / \mathrm{BSc}$ level altogether $86 \%$, at MA/MSc level $88 \%$ of the normative subjects are taught in Ukrainian language. Nevertheless he points out the following reasons behind the phenomenon:

8 The speech can be found in Ukrainian at: http://www.mon.gov.ua/main.php? query=newstmp/2008/21_03

9 See letters ?1/9-189. and 1/9-201 (written on 2 April, 2008) of the Ministry of Education and Science of Ukraine on the following website: http:// www.mon.gov.ua 
- Lack of teachers' terminological knowledge in Ukrainian language;

- Lack or small sample of books, methodological materials published in Ukrainian language;

In order to get the solution for the problems, and to settle the foundation of quality higher education in Ukraine, the Minister brings the attention of the rectors and of the Ministry's Higher Educational Department to the following factors, which are necessary to provide quality higher education:

- one of the obligatory prerequisites of signing contracts with teachers working in higher education should be to hold the lessons in Ukrainian language;

- Ukrainian language trainings should be organised for professors, teachers working in higher education establishments;

- teachers should be convinced to teach their lessons in Ukrainian;

- computer programmes and operational systems in Ukrainian should be made widely used;

- in the process of formation the hierarchy of higher education establishments, one of the defining factors taken into consideration should be the ratio of subjects taught in the official language and book-supply in Ukrainian;

- introducing Ukrainian as the obligatory language at the defences of dissertations and degree papers;

- in case of students from abroad lectures should be taught in Ukrainian, too;

Taking into consideration the previously mentioned things, it is absolutely not surprising that in the 23 page long speech of the minister there is no mention of higher education with minority languages as a medium of instruction. Moreover, we can not be surprised that teaching foreign languages is mentioned in only one paragraph, where he declares that because the task of forming the bases of foreign languages is the responsibility of the secondary school, higher education has only the role to develop them. He points out that at faculties of natural sciences only Ukrainian language, history of Ukrainian culture, one foreign language and philosophy are necessary from the wide range of human subjects.

Current issues in the Ukrainian education policy obviously referring to a language policy, which ends in a situation, where not 
only minority languages will loose their position in education, but also the role of such big European lingua franca-s like English or German will be restricted too.

It is an exciting question what are the opinions of the representatives of Hungarian minority higher education: how are they preparing for the reception of the new Law? With what kind of strategies would they try to reflect the new trend of the Ukrainian educational policy? Evidently, the competent answer could only be formed by a person, who has leading position at the given universities. So in 2009 spring I asked one representative of each university in order to get a better view.

Let's see the main aspects of the interviews. My starting point was that the tasks of a minority university are more complex than an ordinary university: besides giving the highest-level workmanship, it should insure language education; moreover, it should provide the combination of the two: education of technical terminology in different languages. It is the case because, ideally, a minority university (through it takes part in the process of shaping the intellectual layer of the community) has serious effect on the future of the minority and can take part in the realisation of the social aims of the community.

According to minority linguists, teachers and politicians (Beregszászi 2002, Orosz, Csernicskó, Kristofori and Ambrus 2008) the social aim of the Hungarian minority in Ukraine is to integrate into the major society by keeping their own identity and language, and having good competences in the state language and in one foreign language as well.

The linguistic aspect of the social aim of Transcarpathian Hungarians is that universities should guarantee such an intellectual layer, which besides their mother tongue, is able to communicate in the state language and in a foreign language too, moreover which is able to do professional activities in these languages.

Therefore our aims should be served only by a multilingual university education model. Neither the absolute mother tongue education, nor the absolute state language education will lead to the graduation of successful, multilingual minority professionals, who are able to integrate to the society (Kontra 2005: 21).

Nevertheless establishing the exact ratio, the status of languages, finding the appropriate educational models is the task of the university (ideally realizing according to a well thought-out concept (let's call it university language policy)). 
In the next part of my paper on the bases of the interviews, I will show how the institutions of Transcarpathian Hungarian higher education are able to make graduates multilingual, further on which are the most important linguistic problems that makes the realization of this model difficult.

In the beginning of the analysis I have to mention that none of the interviewees speak about an overarching, written language policy, which has reference to all of the mentioned languages.

The status of languages used as the media of instruction is not stable in any of the examined institutes. The fact that which subject will be taught in which language mainly depends on the language skills of the teacher. Nevertheless it is quite rare that the teacher can speak (in an appropriate level for teaching) the state language and the minority language at the same time. It is the case because we have no bilingual teacher training, and teachers have got their education and scientific degree either in the state language or in Hungarian (mainly in Hungary).

It is another crucial problem that Ukraine (despite the fact that on the 19th of May, 2005 it had joined to the Single European Higher Education Area) doesn't acknowledge $\mathrm{PhD}$ degrees getting in Hungary. This problem came hard on the Transcarpathian Hungarian College, where from the beginning until the recent past Hungarian was the absolute medium; the majority of teachers have got their scientific degree in Hungary. Since the state refused to acknowledge their degrees, the institute was forced to apply lecturers who got their degree in Ukraine in Ukrainian language. Among these lecturers there are just a few, who speak Hungarian, and the number of those who intend to teach in Hungarian is even smaller.

On the other side, the level of state language knowledge among Hungarian pupils in Ukraine makes difficult the realization of the multilingual education model, since students who enter the university after studying in a minority school practically do not speak the state language. If we take into consideration the distinction made by Cummins (2008) between basic interpersonal communicative skills (BICS, which refers to conversational fluency in a language) and cognitive academic language proficiency (CALS, which refers to students' ability to understand and express, both oral and written modes, concepts and ideas that are relevant to success in school) we have to admit that even if studying subjects in the state language would be necessary to reach high level of technical language skills in Ukrainian, the level of students' lan- 
guage knowledge do not make it feasible. However, when universities introduce lectures instructed in the state language, obviously do not bear in mind this aspect, and the probable negative effects of it on the output of the educational process.

Still, if the Hungarian higher education would like to help its graduates in the integration, than it should take over the responsibility of the secondary school and improve the level of state language knowledge of the students.

All of the interviewees mentioned the problem and showed intention to find some kind of solution. However practices applying to improve state language skills of the students are different in the examined institutions.

The most frequently used methods applying in state language education:

$>$ Language courses (every institute)

$>$ The reform of the methodology of teaching Ukrainian language (National University of Uzhgorod (NUU)*)

$>$ Courses on technical terminology (Transcarpathian Hungarian College, NUU*)

$>$ Inner language exam (Transcarpathian Hungarian College)

$>$ (partly) medium of instruction (every institute)

$>$ Hostel, environment (NUU*, State University Mukachevo)

$>$ Student mobility $\left(\mathrm{NUU}^{*}\right)$

It is very important that we can only speak about a consistent concept behind the applied methods in the case of the Transcarpathian Hungarian College. It is not exactly a university language policy which quite frequent in western and northern European universities ${ }^{10}$, but something close to that. The college through the concept adjust strategies to students' needs, while in the case of the National University of Uzhgorod the interviewee in most of the cases spoke about desired methods (see *mark), which practically are not used at the moment.

While the higher education in Europe suffers from the extensive spread of English (Phillipson 2003, 2006), in Ukraine foreign language teaching is in its infancy. Every interviewee admitted

10 See for example the University of Helsinki Language Policy: http://www.ub.edu/ slc/socio/Policy_Helsinki.pdf 
that those who are not studying a foreign language as their major, will not acquire the language. A new decree ${ }^{11}$ of the Ukrainian education policy may change the situation concerning foreign language learning, because from 2010 every applicant of the MA level should take a foreign language exam.

To sum up current issues in the state language policy in Ukraine can be very dangerous for the present position of minority languages in education. Our anxiety can be enhanced by the fact that our institutes are not well-prepared to meet the challenges.

It is high time for every institute to work out an individual university language policy taking into account their own aims and personal conditions (language skills and needs of the students and lecturers). However, as a long range aim we need the reformation of the whole Hungarian educational system, with special attention to state-language education in minority schools, bilingual teacher training and bilateral degree-acquisition agreements.

\section{Address:}

Viktória Ferenc

Main street 1

89430 Palló

Ukraine

E-mail: fevikt@gmail.com

\section{References}

Beregszászi, A. (2002) “A kárpátaljai magyarság nyelvhasználati sajátosságai a nyelvtervezés szemszögébõl". [Characteristics of the Transcarpathian Hungarian language use from the point of view of language planning.] Kisebbségkutatás 2, 368-375.

Beregszászi, A. and Csernicskó, I. (2004) “Az anyanyelvet nem megõrizni, hanem használni kell! A Regionális vagy Kisebbségi Nyelvek Európai Kartája és a kárpátaljai magyarság”. [Mother tongue should not be reserved but should be used! The European Charter for Regional and Minority Languages and the Transcarpathian Hungarians.] In A. Beregszászi and I. Csernicskó, eds. ...itt mennyit ér a szó? Írások a kárpátaljai magyarok nyelvhasználatáról, 23-24. Ungvár: PoliPrint.

11 Пункт 7.11. Умов прийому до вищих навчальних закладів Украӥни. Затверджено Наказом Міністерства освіти інауки України від 18.09.2009 № 873. 


\section{Viktória Ferenc}

Csernicskó, I. (1998) A magyar nyelv Ukrajnában (Kárpátalján). [Hungarian language in Ukraine (in Transcarpathia).] Budapest: Osiris Kiadó - MTA Kisebbségkutató Mûhely.

Csernicskó, I., ed. (2003) A mi szavunk járása-Bevezetés a kárpátaljai magyar nyelvhasználatba. [Our speech-An Introduction to the Transcarpathian Hungarian language use.] Ungvár: PoliPrint.

Csernicskó, I. (2008) “Nyelv és azonosságtudat összefüggései a kárpátaljai magyar közösségben". [The coincidence of language and identity in the Transcarpathian Hungarian community).] In Cs. Fedinec, ed. Értékek, dimenziók a magyarságkutatásban, 153-170. Budapest: Magyar Tudományos Akadémia Magyar Tudományosság Külföldön Elnöki Bizottság.

Cummins, J. (2008) "BICS and CALPS: Empirical and theoretical status of the distinction". In B. Street and N. H. Hornberger, eds. Encyclopedia of language and education. Vol. 2: Literacy. 2nd ed., 71-83. New York: Springer Science + Business Media LLC

Kontra, M. (2005) “Tannyelv, (felsõ)oktatás, nyelvpolitika”. [Medium of instruction, (higher)education, language policy.] In M. Kontra, ed. Sült Galamb? Magyar egyetemi tannyelvpolitika, 17-39. Somorja-Dunaszerdahely: Lilium Aurum Könyvkiadó.

Molnár, J. (2004) “Kárpátalja lakosságának nyelvi összetétele a 2001-es ukrajnai népszámlálás adatai alapján”. [The linguistic content of the Transcarpathian population based on 2001 census data.] In A. Beregszászi and I. Csernicskó, eds. Tanulmányok a kárpátaljai magyar nyelvhasználatról, 119-130. Ungvár: PoliPrint.

Orosz, I. and I. Csernicskó (1999) The Hungarians in Transcarpathia. Budapest: Tinta Publishers.

Orosz, I., I. Csernicskó, O. Kristofori, and P. Ambrus (2008) A magyar nyelvû/ nyelvi oktatás stratégiai kérdései Kárpátalján. [Strategic questions of education in /of Hungarian language in Transcarpathia.] Retrieved May 19, 2009, from: http://www.nemzetpolitika.gov.hu/data/files/133843334.pdf

Phillipson, Robert (2003) English-only Europe? Challenging language policy. London: Routledge.

Phillipson, R. (2006) "English, a cuckoo in the European higher education nest of languages?". European Journal of English Studies 10, 1, 13-32.

Shamshur, O. V. and T. I. Izhevskaya (1994) "Multilingual Education as a Factor of Inter-Ethnic Relations: The Case of the Ukraine". Current Issues in Language in Society 1, 1, 29-39.

Shohamy, Elena (2006) Language policy: hidden agendas and new approaches. Abingdon: Routledge.

Shulha, M. (1995) (Шульга М.) "Політико-правові моделі забезпечення прав національних меншин”. [The political-legal model of ensuring 
rights of national minorities.] In Politichnij portret Ukrajini. Bjuleten DNC “Дем. Ініціативи” 14.

Kokkuvõte.Viktória Ferenc: Väljakutsed ungarikeelsele kõrgharidusele Ukrainas. Ukraina ungarlastel on hästi korraldatud haridussüsteem, mis toimib lasteaiast ülikoolini. Esmapilgul näib, et TagaKarpaatia ungarlaste säilimine Ukrainas on kindlustatud, kuid siiski on vaja märgata, et vähemusrahvuse haridust, mis on kogukonna säilimise võtmeküsimus, ohustavad mitmed tegurid. Käesolevas artiklis käsitletakse neist vaid kahte. Ühelt poolt soosib Ukraina riigi keelepoliitika riigikeele positsiooni tugevdamist (seda isegi teiste keelte arvelt) ning haridust kasutatakse selle saavutamiseks. Teiselt poolt, kuna haridus on üks tõhusamaid ja võimsamaid vahendeid vähemuste sotsiaalsete eesmärkide saavutamiseks ja õppekeele valik on keeleõppe poliitikas võtmeküsimuseks, siis on vähemusrahvuste ülikoolid keelekorralduse unarusse jätnud. On ülim aeg, et iga ülikool töötaks välja oma individuaalse keelepoliitika, võttes arvesse oma eesmärke ja tegelikke tingimusi.

Märksõnad: vähemuste haridus, keelepoliitika, õppekeel, ülikoolid 
